\title{
PERUBAHAN GAYA BELAJAR DI MASA PANDEMI COVID-19
}

\author{
EVY ALDIYAH \\ Guru IPA SMP Negeri 202 Jakarta \\ evyaldy@gmail.com
}

\begin{abstract}
ABSTRAK
Pembelajaran Jarak Jauh dimulai seiring meningkatnya pandemi covid-19, mengiikuti kebijakan yang diatur oleh pemerintah. Akibat dari salah satu kebijakan tersebut adalah berubahnya cara belajar siswa dan cara mengajar guru. Perubahan tersebut juga membuat perubahan gaya belajar. Literature review ini bertujuan untuk mengumpulkan dan menganalisa serta mencari kesamaan pandangan terhadap perubahan gaya belajar siswa dan guru selama masa pandemi, serta dapat memberikan kontribusi keilmuan di masa mendatang. Menggunakan desain literature review dengan artikel dan jurnal yang terbit pada rentang waktu bulan Juni 2020 sampai dengan Desember 2020. Dari 5 artikel terpilih dan telah dianalisa di dapat hasil bahwa pembelajaran daring di masa pandemi covid-19 membawa perubahan gaya belajar siswa. Ada perubahan gaya belajar positif dimana siswa menjadi lebih aktif dan kreatif, ada juga perubahan negatif dimana terjadi penurunan motivasi belajar siswa. Pendidik (guru dan dosen) adalah kunci utama sebagai penentu perubahan gaya belajar di masa pandemi covid-19 ini dan dituntut untuk kreatif dan inovatif dalam membangun minat dan motivasi belajar siswa. Disamping itu teknologi juga perlu terus ditingkatkan kualitasnya sebagai sarana terpenting yang mendukung proses tersebut. Pemerintah diharapkan tidak menutup mata terhadap masalah yang terjadi terkait dengan teknologi sebagai sarana pendukung pembelajaran daring atau pembelajaran jarak jauh.
\end{abstract}

Kata kunci : pandemi, perubahan, gaya belajar, daring

\section{PENDAHULUAN}

Sejak pandemi covid-19 mulai meningkat, pembelajaran di sekolah pun mulai diberlakukan dengan sistem baru yaitu pembelajaran jarak jauh, tidak ada lagi aktivitas seperti biasanya karena semua dilakukan dari rumah saja. Maka perubahan kebijakan terhadap dunia pendidikan Indonesia pun tak terelakkan. Kebijakan tersebut dikeluarkan melalui Surat edaran Nomor 4 Tahun 2020, yaitu tentang Pelaksanaan Kebijakan Pendidikan dalam Masa Darurat Penyebaran Coronavirus Disease (Covid19) tertanggal 24 Maret 2020, dimana menganjurkan untuk tetap melaksanakan proses belajar mengajar dari rumah melalui pembelajaran daring (Pusdiklat Pegawai Kementerian Pendidikan dan Kebudayaan, 2020)

Ada enam kebijakan yang telah dipaparkan oleh Menteri Pendidikan dan Kebudayaan RI, Nadiem Anwar Makarim terkait kegiatan pembelajaran di masa pandemi covid-19. Dari enam kebijakan tersebut ada satu kebijakan yang mendasar yaitu berubahnya cara belajar siswa dan cara mengajar guru. Sehingga hal ini pun 
berimbas pada kebiasaan atau perilaku siswa dan guru dalam kegiatan belajar mengajar. Istilah yang digunakan dalam sistem belajar tersebut adalah pembelajaran jarak jauh secara daring (online) dan luring (offline).

Pembelajaran jarak jauh merupakan suatu metode pembelajaran dimana proses belajarnya terpisah, komunikasi antara guru dan siswa harus difasilitasi media elektronik, sebagaimana yang dikemukakan oleh Moore (1973) dalam admin Padamu (2015). Pembelajaran jarak jauh ini dinilai positif dalam membantu berlangsungnya pembelajaran selama masa pandemi. Namun untuk mengubah kebiasaan sangatlah sulit, terlebih lagi kebiasaan belajar mengajar yang sudah berlangsung sekian lama mengalami perubahan dengan tiba-tiba yang terasa cepat tanpa diduga sebelumnya, inilah yang dialami di saat sekarang.

Tentu saja siswa mau tak mau harus mampu mengubah gaya belajar, begitu pula guru, dimana guru diharap mampu mengubah strategi dan metode belajar, mengubah gaya belajar yang selama ini dilakukan. Selain itu antara guru dan siswa pun tetap harus terjalin komunikasi meskipun terpisah jarak, dan terutama sekali adalah memberikan pengalaman belajar yang bermakna bagi siswa. Langkah yang dinilai tepat untuk mengatasi masalah ini adalah menggunakan teknologi jaringan dan informasi. Namun secara menyeluruh kita memang belum siap untuk melakukan perubahan gaya pembelajaran daring saat ini. Karena pelaksanaan pembelajaran daring itu sendiri sangat menuntut kesiapan dari pihak penyedia layanan, begitu pula kesiapan guru dan siswa.

Menururt Gikas dan Grant (2013) dalam Sadkin dan Hamidah (2020), perangkat mobile seperti smartphone android, laptop, komputer, tablet, dan iphone merupakan sarana penunjang pada pembelajaran daring untuk mengakses informasi kapan saja dan dimana saja. Namun kendala utama yang banyak dijumpai adalah masalah teknis, masalah penggunaan aplikasi yang dipakai hingga masalah kuota dan sinyal, terlebih lagi masalah dari siswa yang terhubung dengan karakter dan gaya belajarnya serta ekonomi keluarga, juga masalah kompetensi guru.

Beragamnya media pembelajaran yang tersedia secara online senantiasa mengikuti perkembangan di masa pandemi ini. .Dalam pembelajaran di masa pandemi Covid-19 ini sekolah mengupayakan agar pembelajaran tetap berjalan seperti biasa melalui penggunaan media sosial seperti aplikasi WhatsApp, Google Sites, Google Classrom, Padlet, Edmodo, atau video conference seperti Google Meet, Zoom dan Webex, hingga aplikasi kuis seperti Kahoot, Quizizz, dan semacamnya (Pratama dan Mulyati, 2020). Atau situs rumah-rumah belajar dan LMS (Learning Management System) yang semakin mengembangkan sayapnya, tak ketinggalan TV-Edukasi milik pemerintahpun turut mengisi proses kegiatan belajar selama masa pandemi . Pemanfaatan aplikasi video pengajaran dalam penyampaian informasi kepada siswa dianggap lebih baik daripada informasi yang berupa narasi, dan pemanfaatan fitur pengiriman pesan juga dapat digunakan sebagai sarana diskusi, serta aplikasi kuis yang memberikan kemudahan dan efisiensi waktu bagi guru terutama dalam hal penilaian hasil pembelajaran.

Disini guru dituntut untuk kreatif dalam menentukan strategi dan metode belajar serta pemilihan media dan aplikasi pembelajaran yang digunakan, juga mengaitkan materi pembelajaran dengan situasi yang ada dengan harapan siswa mudah 
memahami materi yang disampaikan dan tidak menjadi bosan. Kemampuan guru berinovasi akan mampu mengubah kebiasaan belajar siswa dengan memperhatikan gaya belajar siswa. Sebagaimana diketahui gaya belajar siswa yang berbeda-beda juga mempengaruhi hasil akhir dari pembelajaran daring ini.

Ada 3 gaya belajar siswa sebagaimana yang dijelaskan oleh Hamzah (2006) dalam Wassahua, S (2016) yaitu 1) Gaya belajar visual (penglihatan), dimana kemampuan mendemonstrasikan lebih tinggi daripada menjelaskan, bukti-bukti konkrit harus diperlihatkan terlebih dahulu agar mereka paham, kesulitan untuk berdialog secara langsung adalah kendala yang biasa ditemukan , 2) Gaya belajar auditori (pendengaran), dimana kemampuan berbicara mendominasi, senang diskusi dan bicara panjang lebar. Siswa dengan gaya belajar ini umumnya cukup susah menyerap secara langsung informasi dalam bentuk tulisan ataupun membaca, dan 3) Gaya belajar kinestetik (gerak), dimana siswa menunjukkan minat belajar melalui praktek langsung. Seseorang yang memiliki gaya belajar ini dapat langsung menyerap informasi tanpa harus membaca penjelasannya hanya dengan memegang bendanya saja, tak tahan duduk manis berlama-lama itulah kendala mereka. Mendengarkan ceramah atau diskusi adalah hal yang dirasa berat bagi siswa yang senang membaca. Demikian juga yang siswa yang kinestetisnya tinggi dan senang bergerak kurang bisa belajar dengan baik jika harus mendengarkan ceramah, begitu pula bagi anak yang suka berdiskusi.

Dalam kondisi saat ini gaya belajar visual tampaknya paling banyak dilakukan, namun ada juga kinestetik, seperti olahraga, praktik sholat, menari dan praktik sains. Ada pun gaya belajar auditori, lebih mengandalkan pada proses mendengar seperti mendengarkan radio belajar atau rekaman suara. Salah satu bagian gaya belajar zaman now adalah video. Untuk menjembatani pertemuan banyak guru menggunakan video conference sebagai pengganti tatap muka di kelas. Namun cukup banyak juga guru yang menggunakan video pembelajaran audio-visual dalam memberikan pembelajaran kepada siswa di rumah. Dan pemberian materi pembelajaran semacam ini dinilai sangat baik dan cukup berpengaruh bagi hasil belajar siswa.

Tujuan literature review ini adalah : (1) Mengumpulkan dan menganalisa serta mencari kesamaan pandangan terhadap perubahan gaya belajar siswa dan guru selama masa pandemi covid-19. (2) . Memberikan kontribusi keilmuan di masa mendatang. Sedangkan manfaat yang diharapkan adalah mengetahui perkembangan pembelajaran jarak jauh yang dicanangkan pemerintah.

\section{METODE LITERATURE REVIEW}

Desain penelitian ini adalah Literature Review. Literature review adalah berupa ulasan, rangkuman, dan pemikiran penulis tentang beberapa sumber pustaka yang dapat berupa artikel, jurnal, buku, slide dan lain-lain terhadap topik yang dibahas seperti yang dikemukakan oleh Hasibuan, Zainal.A (2007) dalam Syafridawaty (2020). Tidak hanya bermakna membaca literarur literature review lebih ke arah evaluasi yang mendalam terhadap suatu topik.

Penelusuran pencarian literatur dengan cara searching pada google search dan google shoolar menggunakan kata kunci. Literatur yang dipilih adalah artikel dan jurnal yang terbit pada rentang waktu bulan Juni 2020 sampai dengan Desember 2020 
yang dapat diakses fulltext-pdf dan berbahasa Indonesia. Artikel atau jurnal yang sesuai dengan kriteria inklusi dan eksklusi diambil untuk selanjutnya dianalisis.

Kritera inklusi literasi review dapat dilihat pada tabel berikut :

Tabel 1. Kriteria Inklusi Kriteria Inklusi

\begin{tabular}{|l|l|}
\hline \multicolumn{1}{|c|}{ Kriteria } & \multicolumn{1}{c|}{ Inklusi } \\
\hline Jangka Waktu & $\begin{array}{l}\text { Penerbitan jurnal bulan Juni 2020 sd } \\
\text { Desember 2020 }\end{array}$ \\
\hline Subjek & Pembelajaran Jarak Jauh \\
\hline Bahasa & Bahasa Indonesia \\
\hline Jenis Jurnal & Artikel penelitian , fulltext pdf \\
\hline Tema & Perubahan gaya belajar \\
\hline
\end{tabular}
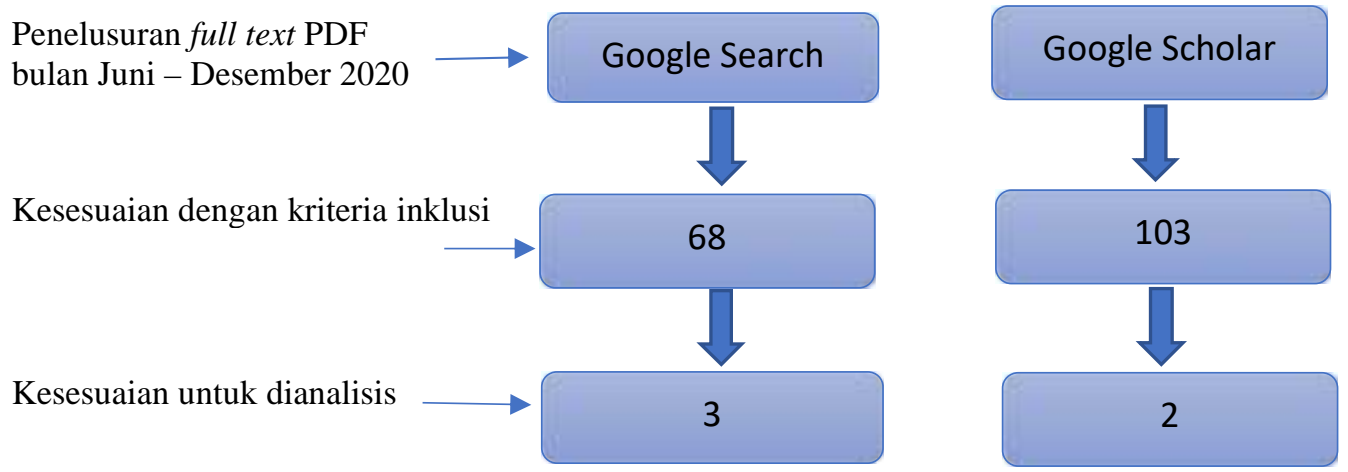

Gambar 1. Skema Pemilihan Artikel

Pada kegiatan analisis dilakukan penguraian kalimat dan bila sudah terkumpul lalu dicari persamaan dan perbedaan pada masing-masing artikel lalu dibahas untuk menarik kesimpulan.

\section{HASIL DAN PEMBAHASAN}

Tabel 2. Hasil Karakteristik 5 Artikel yang Dipilih

\begin{tabular}{|c|c|c|c|c|}
\hline Artikel & Tujuan & Metode & Sampel & Hasil \\
\hline $\begin{array}{l}\text { 1.Analisis Keaktifan } \\
\text { Belajar Siswa Selama } \\
\text { PembelajaranDaring } \\
\text { Pada Masa Covid-19 } \\
\text { di Sekolah Dasar }\end{array}$ & $\begin{array}{l}\text { Menganalisis } \\
\text { keaktifan } \\
\text { belajar siswa } \\
\text { selama } \\
\text { pembelajara } \\
\mathrm{n} \text { daring di }\end{array}$ & $\begin{array}{l}\text { Menggunakan } \\
\text { metode } \\
\text { deskriptif } \\
\text { kualitatif , } \\
\text { narasumber } \\
\text { dijaring }\end{array}$ & $\begin{array}{l}\text { Guru dan siswa } \\
\text { kelas V SDN } \\
\text { Padabeunghar. }\end{array}$ & $\begin{array}{l}\text { Hasil } \\
\text { menunjukkan } \\
\text { bahwa selama } \\
\text { pembelajaran } \\
\text { daring } \\
\text { berlangsung }\end{array}$ \\
\hline
\end{tabular}




\begin{tabular}{|c|c|c|c|c|}
\hline $\begin{array}{l}\text { (Naziaha, T. Syifa, et } \\
\text { all, 2020) }\end{array}$ & $\begin{array}{l}\text { masa } \\
\text { pandemi } \\
\text { covid-19 }\end{array}$ & $\begin{array}{l}\text { dengan } \\
\text { metode yang } \\
\text { alamiah yakni } \\
\text { interview } \\
\text { langsung }\end{array}$ & & $\begin{array}{l}\text { keaktifan } \\
\text { belajar siswa } \\
\text { tidak } \\
\text { sepenuhnya } \\
\text { dapat dicapai } \\
\text { oleh siswa }\end{array}$ \\
\hline $\begin{array}{l}\text { 2.Efektivitas } \\
\text { Pembelajaran Daring } \\
\text { pada Masa Pandemi } \\
\text { Covid-19 (Harnani, } \\
\text { Sri, 2020) }\end{array}$ & $\begin{array}{l}\text { Mengetahui } \\
\text { gambaran } \\
\text { gaya belajar } \\
\text { siswa } \\
\text { terhadap } \\
\text { hasil belajar }\end{array}$ & $\begin{array}{l}\text { Menggunakan } \\
\text { metode } \\
\text { deskritif } \\
\text { kualitatif } \\
\text { yakni ilustrasi } \\
\text { secara } \\
\text { sistematis, } \\
\text { akurat, } \\
\text { mengenai } \\
\text { fenomena } \\
\text { yang diteliti. }\end{array}$ & $\begin{array}{lr}\text { Siswa } & \text { SMP } \\
\text { Negeri } & \text { Karang } \\
\text { Jaya } & \end{array}$ & $\begin{array}{l}\text { Hasil } \\
\text { menunjukkan } \\
\text { bahwa gaya } \\
\text { belajar sangat } \\
\text { menentukan } \\
\text { keberhasilan } \\
\text { dalam proses } \\
\text { pembelajaran }\end{array}$ \\
\hline $\begin{array}{l}\text { 3.Motivasi } r \text { Belajar } \\
\text { Siswa SMA pada } \\
\text { Pembelajaran Daring } \\
\text { di Tengah Situasi } \\
\text { Pandemi Covid-19 } \\
\text { (Cahyani, Adhetya et } \\
\text { all, 2020) }\end{array}$ & $\begin{array}{l}\text { Mengetahui } \\
\text { motivasi } \\
\text { belajar siswa } \\
\text { SMA pada } \\
\text { pembelajara } \\
\text { n daring }\end{array}$ & $\begin{array}{l}\text { Menggunakan } \\
\text { pendekatan } \\
\text { kuantitatif, } \\
\text { dengan teknik } \\
\text { accidental } \\
\text { sampling } \\
\text { menggunakan } \\
\text { google form }\end{array}$ & $\begin{array}{l}\text { Seluruh siswa } \\
\text { SMA/SMK/M } \\
\text { A yang ada di } \\
\text { Indonesia yang } \\
\text { mengikuti } \\
\text { proses } \\
\text { pembelajaran } \\
\text { dengan sistem } \\
\text { online atau } \\
\text { daring. }\end{array}$ & $\begin{array}{l}\text { Hasil } \\
\text { menunjukkan } \\
\text { bahwa nilai } \\
\text { siginifikansi } \\
\text { Mann Whitney } \\
\text { U sebesar } 0,000 \\
\text { yang artinya } \\
\text { motivasi } \\
\text { belajar pada } \\
\text { siswa yang } \\
\text { mengikuti } \\
\text { pembelajaran } \\
\text { daring atau } \\
\text { online di } \\
\text { tengah situasi } \\
\text { pandemik virus } \\
\text { Covid-19 ini } \\
\text { menurun, } \\
\text { karena nilai } \\
\text { signifikansi } \\
\text { yaitu 0,000 } \\
\text { adalah kurang } \\
\text { dari } 0,05 \text { (p < } \\
0,05 \text { ). }\end{array}$ \\
\hline $\begin{array}{l}\text { 4. Pembelajaran } \\
\text { Daring Dan } \\
\text { Luring Pada }\end{array}$ & $\begin{array}{l}\text { Mencari tahu } \\
\text { bagaimana } \\
\text { penerapan } \\
\text { pembelajara } \\
\mathrm{n} \text { daring dan }\end{array}$ & $\begin{array}{l}\text { Menggunakan } \\
\text { metode } \\
\text { fenomenologi } \\
\text { untuk melihat }\end{array}$ & $\begin{array}{l}\text { Guru-guru di } \\
\text { salah satu SMA } \\
\text { di Kabupaten } \\
\text { Ogan Komering } \\
\text { Ulu Timur, }\end{array}$ & \begin{tabular}{l}
\multicolumn{3}{l}{ Hasil } \\
menunjukkan \\
bahwa guru \\
menjadi lebih \\
kreatif dan
\end{tabular} \\
\hline
\end{tabular}




\begin{tabular}{|c|c|c|c|c|}
\hline $\begin{array}{l}\text { Masa Pandemi } \\
\text { Covid-19. (Pratama, } \\
\text { E.Rio dan Mulyati, } \\
\text { Sri, 2020) }\end{array}$ & $\begin{array}{l}\text { pembelajara } \\
\text { n luring }\end{array}$ & $\begin{array}{l}\text { fenomena } \\
\text { yang terjadi } \\
\text { dalam } \\
\text { kehidupan di } \\
\text { masyarakat, }\end{array}$ & $\begin{array}{l}\text { Sumatera } \\
\text { Selatan, } \\
\text { Indonesia yang } \\
\text { berjumlah } 41 \\
\text { orang }\end{array}$ & $\begin{array}{l}\text { peran guru } \\
\text { tidak bisa } \\
\text { digantikan } \\
\text { dengan apapun }\end{array}$ \\
\hline $\begin{array}{l}\text { 5. Pembelajaran } \\
\text { Daring di Tengah } \\
\text { Wabah Covid-19 } \\
\text { (Sadikin, A dan } \\
\text { Hamidah,A,2020) }\end{array}$ & $\begin{array}{l}\text { Memperoleh } \\
\text { gambaran } \\
\text { pelaksanaan } \\
\text { pembelajara } \\
\text { n daring }\end{array}$ & $\begin{array}{l}\text { Menggunakan } \\
\text { metode } \\
\text { survey } \\
\text { menggunakan } \\
\text { google form } \\
\text { melalui pesan } \\
\text { WhatsApp }\end{array}$ & $\begin{array}{l}\text { Mahasiswa } \\
\text { Program studi } \\
\text { Pendidikan } \\
\text { Biologi FKIP } \\
\text { Universitas } \\
\text { Jambi yang } \\
\text { melaksanakan } \\
\text { pembelajaran } \\
\text { daring, } \\
\text { sebanyak } 96 \\
\text { orang }\end{array}$ & $\begin{array}{l}\text { Hasil } \\
\text { menunjukkan } \\
\text { bahwa } \\
\text { mahasiswa } \\
\text { merasa lebih } \\
\text { nyaman dan } \\
\text { dalam } \\
\text { mengemukaka } \\
\text { n gagasan dan } \\
\text { pertanyaan } \\
\text { dalam } \\
\text { pembelajaran } \\
\text { daring, lebih } \\
\text { kreatif dalam } \\
\text { membuat } \\
\text { tugas-tugas dan } \\
\text { tidak } \\
\text { merasakan } \\
\text { tekanan } \\
\text { psikologis }\end{array}$ \\
\hline
\end{tabular}

Pada artikel penelitian nomor 1, dimana siswa hanya mengikuti pembelajaran daring melalui salah satu aplikasi yang sudah familiar yaitu Whatsapp. Banyak kendala yang dialami siswa seperti tidak tersedianya gawai sebagai media, kemampuan siswa yang terbatas dalam mengoperasikan gawai dengan aplikasi online, dan dukungan orangtua yang minim. Dari 6 indikator mengenai keaktifan belajar siswa hanya beberapa siswa yang dapat mencapai ke enam indikator tersebut. Tentunya perhatian pemerintah sangat dibutuhkan disini.

Pada artikel penelitian nomor 2, berhasil atau gagalnya siswa dalam proses pembelajaran tergantung dari gaya belajar yang dimilikinya. Bila gaya belajarnya sejalan dengan kemampuannya maka hasil belajarnya juga baik, dan itu tak lepas dari guru sebagi kuncinya, kreatif dan inovatif dalam memiih metode pembelajaran.

Pada artikel nomor 3, dimana pembelajaran daring membuat guru dan siswa tidak dapat bertatap muka secara langsung tetapi dengan perantara teknologi informasi, sehingga membuat situasi baru yang harus dihadapi siswa dan memberikan dampak negatif pada motivasi belajar siswanya. Motivasi belajar siswa menurun selama 
pembelajaran daring juga dikarenakan faktor lingkungan di rumah. Disini guru benarbenar dituntut harus kreatif dan inovatif mengubah gaya belajar sebagai solusinya.

Pada artikel penelitian nomor 4, dimana sekolah tersebut sudah menggunakan berbagai cara pembelajaran daring menggunakan media sosial seperti aplikasi WhatsApp, Google Classrom, Google Meet, Edmodo dan Zoom. Tampak siswa lebih menyukai dan menjadi tertarik sehingga siswa menjadi lebih aktif. Dihadapkan dengan kendala sehubungan dengan masih tidak tersedianya gawai yang dimiliki siswa, maka sekolah ini mencoba menggunakan pembelajaran luring. Pembelajaran tatap muka dilakukan terbatas yaitu separuh dari jumlah siswa dalam satu kelas.

Pada artikel nomor 5, dimana kelas virtual yang diberikan dosen dalam perkuliahan dan mudah diakses mahasiswanya dimana pun dan kapan pun, pembelajaran daring ini mampu membuat mahasiswa semakin mandiri dalam belajar. Kuncinya adalah bagaimana kreatif dan inovasi dosen dalam memilih metode pembelajaran yang sesuai.

Perbedaan hasil penelitian ke lima artikel tersebut selain faktor metode penelitian yang digunakan faktor jenjang pendidikan juga cukup berpengaruh terhadap kebiasaan belajar dan perubahan gaya belajar terkait dengan perkembangan kognitifnya. Dibutuhkan pemahaman tentang perkembangan kognitif anak dalam menentukan strategi, model, metode dan tekik evaluasi dalam pembelajaran.

Persamaan yang dapat ditemukan dari literature review terhadap ke lima artikel tersebut adalah tampak adanya perubahan gaya belajar. Pada artikel nomor 2, nomor 4 dan nomor 5, tampak sekali perubahan positif gaya belajar siswa/mahasiswa di masa pandemi covid-19 ini melalui pembelajaran daring. Sedangkan pada artikel nomor 1 masih kurang mengena karena masih sebagian siswa dinilai tidak sepenuhnya aktif dalam pembelajaran daring. Disini dituntut kreatifitas dan inovasi guru untuk membangun keaktifan belajar siswanya. Sementara pada artikel nomor 5 dimana terjadi penurunan motivasi pada siswa di masa pembelajaran daring, ini menjadi catatan penting dan pekerjaan rumah bagi guru untuk membangun kembali minat dan motivasi belajar siswanya.

Dengan adanya perubahan gaya belajar siswa diharapkan mampu mengembangkan kemampuan dan pengetahuan yang diperolehnya sehingga bermanfaat pula dalam proses pembelajaran atau menyelesaikan soal tes. Dan penting bagi guru untuk mengetahui bagaimana gaya belajar siswanya dan bagaimana kesiapan siswa menerima informasi yang dia berikan, dengan harapan proses belajar mengajar menjadi lebih efektif.

Akhirnya menjadi tantangan bagi guru dan siswa dalam mengembangkan gaya belajar terkait pemanfaatan teknologi pembelajaran yang harus dikuasai dimasa pandemi covid-19 ini. Pembelajaran jarak jauh masih perlu terus disempurnakan agar semakin efektif sehingga memungkinkan siswa dapat lebih terlibat dalam proses pembelajaran. Itu bearti guru juga semakin kreatif dan inovatif dalam menentukan strategi, metode pembelajaran dan media yang sesuai dengan gaya belajar siswanya. Teknologi juga perlu terus ditingkatkan kualitasnya sebagai sarana terpenting yang mendukung proses. Karena efektif tidaknya program pembelajaran jarak jauh tidak hanya dilihat dari hasil prestasi belajar saja, melainkan harus ditinjau pula dari segi proses, gaya belajar dan sarana pendukungnya. 


\section{KESIMPULAN DAN SARAN}

Kesimpulan : (1) Dari literature review terhadap 5 artikel yang dipilih ditemukan persamaan yaitu adanya perubahan gaya belajar. Pembelajaran daring di masa pandemi covid-19 membawa perubahan gaya belajar siswa. Ada perubahan gaya belajar positif dimana siswa menjadi lebih aktif dan kreatif, ada juga perubahan negatif dimana terjadi penurunan motivasi belajar siswa. (2) Pendidik (guru dan dosen) adalah kunci utama dalam penentu perubahan gaya belajar di masa pandemi covid-19 ini dan dituntut untuk kreatif dan inovatif dalam membangun minat dan motivasi belajar siswa.

Saran : Pemerintah diharapkan tidak menutup mata terhadap masalah yang terjadi terkait dengan teknologi sebagai sarana pendukung pembelajaran daring atau pembelajaran jarak jauh ini.

\section{DAFTAR PUSTAKA}

Admin Padamu. www.padamu.net.pengertian-pembelajaran-jarak-jauh-menurutahli. , diakses 18 September 2020

Cahyani, Adhetya. et all (2020). Motivasi Belajar Siswa SMA pada Pembelajaran Daring di Tengah Situasi Pandemi Covid-19. e-Jurnal Pendidikan Islam Vol. 3 No. 01. DOI: https://doi.org/10.37542/iq.v3i01.57

Harnani,Sri (2020). http://bdkjakarta.kemenag.go.id.efektivitas-pembelajaran-daringdi-masa-pandemi-covid-19, diakses 7 Juli 2020

Naziaha, T.Syifa et all (2020) . Analisis Keaktifan Belajar Siswa Selama Pembelajaran Daring Pada Masa Covid-19 di Sekolah Dasar. e-JURNAL JPSD Vol.7 No. 2 Tahun 2020 ISSN 2356-3869 (Print), 2614-0136 (Online), DOI:http//dx.doi.org/10.26555/jpsd, diakses 25 Agustus 2020

Pratama, E. Rio dan Mulyati, Sri (2020). Pembelajaran Daring dan Luring Pada Masa Pandemi Covid-19. e-Jurnal Gagasan Pendidikan Indonesia Vol. 1 No. 2 . 29 Oktober 2020.ISSN 2721-9240

Pusdiklat Pegawai Kementerian Pendidikan dan Kebudayaan (2020). "SURAT EDARAN MENDIKBUD NO 4 TAHUN 2020 TENTANG PELAKSANAAN KEBIJAKAN PENDIDIKAN DALAM MASA DARURAT PENYEBARAN CORONA VIRUS DISEASE (COVID- 1 9),” 24 Maret 2020. https://pusdiklat.kemdikbud.go.id/surat-edaran-mendikbud-no-4-tahun-2020tentang-pelaksanaan-kebijakan-pendidikan-dalam-masa-darurat-penyebarancorona-virus-disease-covid-19

Rahayu, Minarti (2015), http://minartirahayu.blogspot.com/2013/pengertian-gayabelajar-berbagai-macam.html, diakses 28 Desember 2015

Sadikin, A dan Hamidah, A (2020). Pembelajaran Daring di Tengah Wabah Covid19. e-Jurnal Ilmiah Pendidikan Biologi ISSN 2580-0922 (online), ISSN 24602612 (print) Volume 6, Nomor 02, Tahun 2020, .https://online.journal.unja.ac.id/biodik.pembelajaran-daring-di-tengahwabah-covid-19, diakses 30 Juni 2020 
Syafridawaty (2020). Literature Review. e-Jurnal Universitas Raharja. http://raharja.ac.id.2020/10/13.literature-review, diakses 13 Oktober 2020

Wassahua, S (2016).Analisis Gaya Belajar Siswa Terhadap Hasil Belajar Matematika Pada Materi Himpunnan Siswa Kelas VII SMP Negeri Karang Jaya Kecamatan Namlea Kabupaten Buru. e-Jurnal Matematika dan Pembelajarannya 2016 Vol. 2, No. 1. ISSN 2303-0992 